\title{
Aspirin is safe and cost-effective in preventing venous thromboembolism prophylaxis in arthroplasty
}

\author{
Aspirin artroplastide venöz tromboembolizm profilaksisini \\ önlemede güvenli ve maliyet-etkindir \\ O. Şahap Atik, MD \\ Department of Orthopedics and Traumatology, Medical Faculty of Gazi University, Ankara, Turkey
}

Venous thromboembolism may cause morbidity and mortality in patients having arthroplasty. Anticoagulation agents like low molecular weight heparin, vitamin $\mathrm{K}$ antagonists, and factor $\mathrm{Xa}$ inhibitors are being used in the prevention of venous thromboembolism.

However, there are several studies reporting aspirin as safe and cost-effective for venous thromboembolism prophylaxis in arthroplasty. ${ }^{[1-3]} \mathrm{Nam}$ et al. ${ }^{[4]}$ presented their experience with the use of a risk stratification protocol for venous thromboembolism prophylaxis in arthroplasty in which standard-risk patients received a mobile compression device in combination with aspirin and high-risk patients received warfarin for thromboprophylaxis. They concluded that use of a risk stratification protocol allowed the avoidance of more aggressive anticoagulation in $70 \%$ of patients. ${ }^{[4]}$

Appropriate patients without hypercoagulability, metastatic cancer, deep vein thrombosis, chronic obstructive pulmonary disease, or obesity may obtain more benefit from traditional and cheaper aspirin prophylaxis than novel and more expensive agents. ${ }^{[5]}$

\section{REFERENCES}

1. Odeh K, Doran J, Yu S, Bolz N, Bosco J, Iorio R. Riskstratified venous thromboembolism prophylaxis after total joint arthroplasty: aspirin and sequential pneumatic compression devices vs aggressive chemoprophylaxis. J Arthroplasty 2016;31(9 Suppl):78-82.

2. Huang RC, Parvizi J, Hozack WJ, Chen AF, Austin MS. Aspirin Is as Effective as and Safer Than Warfarin for Patients at Higher Risk of Venous Thromboembolism Undergoing Total Joint Arthroplasty. J Arthroplasty 2016;31(9 Suppl):83-6.

3. Bala A, Huddleston JI 3rd, Goodman SB, Maloney WJ, Amanatullah DF. Venous Thromboembolism Prophylaxis After TKA: Aspirin, Warfarin, Enoxaparin, or Factor Xa Inhibitors? Clin Orthop Relat Res 2017;475:2205-2213.

4. Nam D, Nunley RM, Johnson SR, Keeney JA, Clohisy JC, Barrack RL. The Effectiveness of a Risk Stratification Protocol for Thromboembolism Prophylaxis After Hip and Knee Arthroplasty. J Arthroplasty 2016;31:1299-306.

5. Atik OŞ. Platelet-rich plasma: Everything new may not be good enough! Eklem Hastalik Cerrahisi 2017;28:63.

\footnotetext{
- Correspondence: O. Şahap Atik, MD. Gazi Üniversitesi Tıp Fakültesi Ortopedi ve Travmatoloji Anabilim Dalı, 06500 Beşevler, Ankara, Turkey. Tel: +90 312 - 2025528 e-mail: satikmd@gmail.com
} 